\title{
Homologous Recombination and Its Role in Carcinogenesis
}

\author{
Alexander J. R. Bishop ${ }^{1}$ and Robert H. Schiest1 ${ }^{2 *}$ \\ ${ }^{1}$ Department of Genetics, Harvard Medical School, Boston, MA 02115, USA \\ ${ }^{2}$ Department of Pathology, UCLA Medical School, Los Angeles, CA 90095, USA
}

Received 9 January 2002; revised 29 April 2002; accepted 29 April 2002

\begin{abstract}
Cancer develops when cells no longer follow their normal pattern of controlled growth. In the absence or disregard of such regulation, resulting from changes in their genetic makeup, these errant cells acquire a growth advantage, expanding into precancerous clones. Over the last decade, many studies have revealed the relevance of genomic mutation in this process, be it by misreplication, environmental damage, or a deficiency in repairing endogenous and exogenous damage. Here, we discuss homologous recombination as another mechanism that can result in a loss of heterozygosity or genetic rearrangements. Some of these genetic alterations may play a primary role in carcinogenesis, but they are more likely to be involved in secondary and subsequent steps of carcinogenesis by which recessive oncogenic mutations are revealed. Patients, whose cells display an increased frequency of recombination, also have an elevated frequency of cancer, further supporting the link between recombination and carcinogenesis.
\end{abstract}

\section{INTRODUCTION}

Genetic alteration is the fundamental underlying process that allows a normal cell to evolve into a cancerous one. Genetic alterations can take a variety of forms with the essential result being that a gene, or a combination of genes, is altered to produce a cell that can bypass normal growth restrictions. Here, we present a body of evidence indicating that one of the important processes of genetic alteration in the generation of cancers is homologous recombination (HR). Evidence from our laboratory, and many others, have demonstrated that certain genetic deficiencies result in higher than normal levels of genomic instability including a higher frequency of HR. Patients with such genomic instability have a higher probability of developing cancers as the instability allows a higher rate of genetic alteration. These alterations may result in either the direct mutation of an oncogenic gene or, more likely, it reveals an already mutated copy. In addition, we present evidence that proliferating cells demonstrate the highest propensity for $\mathrm{HR}$, in effect this predisposes proliferating cancer cells to an increased frequency of this form of genomic instability.

\section{MODELS OF CARCINOGENESIS}

Here, we mention three commonly accepted models of carcinogenesis to highlight some of the processes that may involve an HR event. The simplest model for carcinogenesis is a one-step event. Most often, a mutation occurs in an oncogene that acts dominantly allowing oncogenesis. Examples of oncogenes include c-ABL1, H-RAS, c-MYC, c-ERBB, v-FOS, and c-JUN [1]. Alternatively, the one-step model involves an inherited recessive defect that is exposed by the mutation of its functional counterpart, though actually, this "mutation" is most often a loss of heterozygosity ( $\mathrm{LOH}$ ) event. These recessive mutations are usually in genes classically called tumour suppressers (for a review see [2]).

A simple two-step model allows for the majority of tumour suppresser genes being present as two functional copies, where both copies have to be mutated to incapacitate functionality [3]. In the published literature, $\mathrm{LOH}$ is the most commonly reported event, as opposed to mutational heterozygosity. Recombination, be it by deletion of the functional allele or gene conversion of the functional allele into the mutated one, is the most likely mechanism for $\mathrm{LOH}$, this is discussed further later in this review.

A multistep scenario has intriguing implications. Here, the initial mutation is the result of a DNA repair or metabolism defect. Such cells may accumulate somatic mutations at a higher frequency or may have a higher level of gross genomic instability. Those patients with a predisposition to genomic instability have a much higher incidence of cancer than the general population, and they have a much earlier onset of certain tumor types. Some of these diseases are outlined later in the review.

As yet it has been difficult to determine which gene is initially mutated in most cancers. The reason is two-fold, firstly, the majority of tumours display heterogeneity $[4,5,6,7]$, often with an associated genetic instability $[8,9,10,11]$. This phenotype may be facilitated by the initial mutation being of a DNA repair gene (see section Genetic instability syndromes below, for reviews see $[6,7])$. Secondly, not all the genes 
that are involved in carcinogenesis have been identified. However, it does appear that several cellular pathways are often altered to produce the necessary changes that produce a cancerous cell.

\section{HOMOLOGOUS RECOMBINATION IN MAMMALIAN} CELLS

Homologous recombination in mammalian cells is often considered to be less prevalent than an alternative recombination pathway, namely, nonhomologous end-joining (NHEJ) [12]. Thus, as a process of DNA repair and carcinogenesis, HR has often been overlooked [13]. This idea is widely accepted as it is well known that a large proportion of the mammalian genome contains repetitive DNA sequences [14]. Contrarily, recent studies have shown that mammalian cells are in fact quite proficient in HR; Liang et al [15] demonstrated that a site specific break between two copies of a gene will result in homologous deletion at a relatively high frequency (30\% to 50\%). Further, the author of [16] determined that sister chromatid exchange is highly prevalent [16], followed by homologous interchromosomal recombination and then by ectopic recombination $[17,18]$. In the last decade we, amongst several other researchers, demonstrated that deletions can be mediated by HR between repeated DNA fragments [19] and that the frequency of these events are elevated following exposure to cancer-causing agents $[20,21,22,23]$.

\section{HOMOLOGOUS RECOMBINATION IN CARCINOGENESIS}

Homologous recombination may be playing a fundamental role in carcinogenesis. In the following sections we outline six situations where HR may have a fundamental part to play in the progression to cancer. Firstly, we believe that the $\mathrm{HR}$ can be a major mechanism in the $\mathrm{LOH}$, fulfilling the second step of the two-step model or a later event in the multistep model. Secondly, there are some cancer prone diseases that have genetic instability as a phenotype, some of these diseases also display an elevated level of HR. An increased frequency of HR makes it more likely that the $\mathrm{LOH}$ will occur at an accelerated rate, but also raises the possibility that HR will cause aberrant genomic rearrangements that may act as the primary step towards carcinogenesis. We also present some recent evidence that HR is more prevalent in proliferating cells. Together, these arguments provide compelling evidence that HR may be an important factor in the multiple steps required for carcinogenesis.

\section{Mechanisms of loss of heterozygosity}

There are various mechanisms that can result in $\mathrm{LOH}$. Basically, the $\mathrm{LOH}$ results from one allele being lost from a cell that is then either homozygous or hemizygous for the remaining allele. Homozygosity can be attained when a gene conversion event occurs. Hemizygosity occurs when one allele is lost, as its DNA is no longer present in the cell.
This latter event may occur by the deletion of the region containing the gene or during the division by chromosome loss.

Gene conversion $[14,24,25]$ is a unidirectional transfer of information. In such an event, DNA is copied [26, 27] from one chromosome or chromatid to another without necessarily altering the arrangement of flanking markers. The frequency by which this HR mechanism occurs is difficult to determine as most gene conversions probably go undetected. Much of our understanding of this and other recombination mechanisms comes from analogous comparison to work performed in the model organism Saccharomyces cerevisiae.

Chromosome loss is a major mechanism of $\mathrm{LOH}$. This type of event results in a deviation in the chromosome number to produce a cell that is aneuploid. It is interesting to note that almost every type of histological cancer carries cells with highly heterogeneous patterns of aneuploidy (for review see [28]). Once aneuploid, cells are often genetically unstable, as seen in cases of congenital aneuploidy. Patients with this congenital abnormality often display a high incidence of neoplasia (for reviews see $[29,30]$ ).

A translocation is the transfer of a part of one chromosome to a nonhomologous chromosome. Translocations are often reciprocal, exchanging two different DNA segments. The break point of a translocation event may occur within a gene, thus destroying its function or altering its expression pattern, for example, the Burkitt lymphoma. One such translocation, the Philadelphia chromosome (chromosome 9/22 translocation), which produces a BCR-ABL1 compound gene and results in chronic myelogenous leukemia. Two studies mapped the breakpoint of the Philadelphia chromosome and found that the translocation was mediated by a region of shared homology [31,32] implicating HR as the mechanism.

There are three basic mechanisms that may produce a DNA deletion event (see Figure 1), the replication slippage, intrachromosomal and interchromosomal recombination. The replication slippage during DNA synthesis may produce a deletion, these deletions tend to be small $[33,34,35,36,37]$ and most often occurin special regions where short tandemly reiterated sequences exist. The most common example of this is microsatellite instability, a phenomenon most prominent in hereditary nonpolyposis colon cancer. The causative mutations of this disease are in the mismatch repair genes resulting in a lack of replication proofreading $[38,39,40,41]$ and, therefore, an increased frequency of replication errors.

Intrachromosomal deletions are the result of aberrant recombination, many times mediated by regions of homology and can remove very large regions of DNA. Such deletions have been identified as the cause of several diseases, which include $\mathrm{X}$-linked ichthyosis where 1.9 Mb, megabases, of DNA are deleted mediated by flanking homologous S232 elements $[42,43]$, hereditary neuropathy with liability to pressure palsies where $1.5 \mathrm{Mb}$ are deleted mediated by CMT1A-REP $[44,45,46]$ as well as Prader-Willi syndrome [47], DiGeorge syndrome [48], and hypercholesterolemia [49], all these examples are due to deletions mediated by HR between flanking regions of homology. There are several mechanisms that may produce an HR mediated intrachromosomal deletion, three of the most likely being an intrachromosomal crossover 


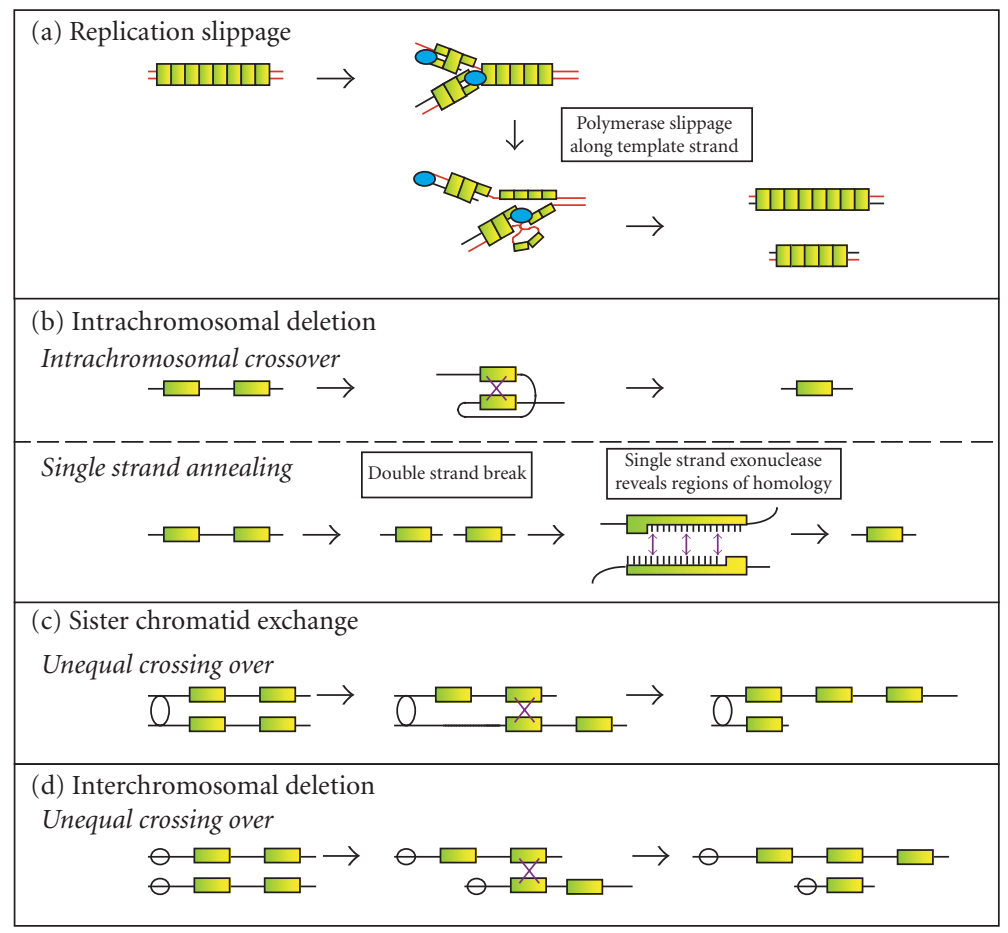

Figure 1. Mechanisms of deletion. (a) Replication slippage, where DNA polymerase dissociates from its template and reanneals to homologous sequences nearby resulting in either a deletion (shown) or insertion (not shown) of sequences. These tend to be relatively small deletions or insertions and are usually in regions of repetitive DNA. (b) Intrachromosomal or intrachromatid deletion may be mediated by a number of different mechanisms, two of the most likely being a crossover event and single strand annealing. A crossover event is mediated by aligning homologous sequences, strand invasion, possibly following a single-stranded break, allows strand exchange and recombination between the two homologous sequences. The result is a deletion of the intervening sequences. Single strand annealing is another likely mechanism that requires a double strand break between the homologous sequences. A single strand exonuclease can degrade one strand at the DNA ends until homology is revealed allowing the broken ends to anneal and the intervening sequences to be clipped off. (c) Interchormatid deletion is most likely to result from an unequal crossover event, only occuring in G2 after the chromatid has been replicated but before they are segregated. Again, the event is mediated by a repeated region of homology, but in these events two products are formed, a deletion and a triplication on the two resultant recombinant chromosomes. (d) Interchromosomal deletion is similar to interchromatid deletion except that the interaction is between homologous chromosomes.

event, single strand annealing (reviewed in [50]), or unequal sister chromatid exchange. Single strand annealing is initiated by a double strand break (DSB) in a nonhomologous region between repeats or within one repeat. DNA degradation of single strands from exposed $5^{\prime}$ ends of DSBs leads to single-stranded regions, which anneal with each other once the degradation has exposed the repeated sequences. The $3^{\prime}$ tails are processed and nicks are ligated, producing the deletion. Unequal sister chromatid exchange may occur during the DNA replication, probably initiated following the replication fork stalling [51]. A deletion results from an unequal crossing over between misaligned homologous regions on sister chromatids producing a deletion on one chromatid and a duplication of the same region on the other, these then segregate in the daughter cells that are produced. The final class of deletion is an interchromosomal event, this is very similar to an unequal sister chromatid exchange, except that the interaction is between homologous chromosomes or ectopic homologous regions and is not necessarily dependent upon replication. It should also be noted that the $\mathrm{LOH}$ by deletion can also be mediated by NHEJ. In these events, two ends of DNA are brought together by two or four bases of microhomology. Many of these types of event have been modelled in yeast [52] and human tissue culture cell systems [53].

Inter and intrachromatid recombination events are only distinguishable by the presence or absence of a reciprocal duplication product. In this respect, it is interesting to note that the Charcot-Marie-Tooth disease type 1A occurs from a duplication of the same region as is deleted in hereditary neuropathy with liability to pressure palsies $[46,54,55]$. Similarly, a tandem duplication within the $A L L-1$ gene is mediated by $A l u$ recombination and results in acute myeloid leukemia [56]. These duplications suggest that an interchromatid crossing over mechanism is responsible for these events.

Gene conversion, deletion, and perhaps translocation may be mediated by HR. In the past decade, we have used homologous deletion to detect genomic instability in a yeast model systems $[57,58]$, in human cells [22] as well as in vivo in mice $[21,23,59]$. Some of the most interesting results from these studies are presented later in this review. 


\section{Genetic instability syndromes}

Assuming that genome rearrangements and deletion events cause a significant proportion of cancers, then there should be a correlation between those mutations that result in a higher recombination frequency and cancer predisposition. In fact, there are several genetic diseases that have a genetic instability phenotype and indeed have a high frequency of carcinogenesis. These include the Ataxia telangiectasia (AT) [60], Li-Fraumeni syndrome [61], Bloom syndrome [62], Werner syndrome [63], Cockayne syndrome, Fanconi anemia, Lynch syndromes I and II, Wiscott-Aldrich syndrome, and xeroderma pigmentosum [64]. Some of these diseases are presented in more detail below.

The Li-Fraumeni syndrome is a dominantly inherited disorder characterized by an early onset of cancer. The most prominent of these cancers are carcinoma of the breast followed by sarcomas, brain tumors, leukemia, lymphoma, lung carcinoma, and adrenocortical carcinoma, usually in children and young adults. The overall risk of cancer in these patients is nearly $100 \%$, with over $50 \%$ of patients developing breast cancer by age 50 (reviewed in [65]). Li-Fraumeni syndrome patients, who carry a recessive mutation in TP53, have an exceptionally high risk of developing multiple primary cancers [66]. p53 has been proposed to be involved in maintaining the stability of the genome $[61,67,68,69,70$, $71,72,73,74]$ by either its function in cell cycle arrest or apoptosis. At early passages, fibroblasts from Trp53-/- mice develop several chromosomal abnormalities [75]. Tumours from Trp53-/- mice are often aneuploid and there has been some evidence of chromosomal instability $[76,77]$. In addition, p53 may inhibit HR via a putative interaction with the HR machinery protein $\operatorname{RAD} 51[71,78]$. How p53 is involved with $\mathrm{HR}$ is still not clearly understood, though many studies have undertaken to examine the relationship, most showing that cells lacking p53 have a higher than normal frequency of $\operatorname{HR}[71,72,73,79,80,81]$.

Ataxia telangiectasia is an autosomal recessive syndrome. Among the phenotypes that patients display are chromosomal instability, radiosensitivity, and a predisposition to lymphoid cancer in childhood. Although AT is a relatively rare disorder, it has been estimated that about $1 \%$ of the general population is heterozygous for ATM mutations [82]. These heterozygous carriers may have a predisposition to sporadic breast cancer, though this correlation is still under discussion (for a review see [83]).

Cells from AT patients display chromosomal instability both spontaneously and following induction by ionizing radiation or radiomimetic agents (reviewed in [84, 85]). Cytogenetic analysis revealed a higher spontaneous incidence of chromosome breaks, chromosome gaps, acentric fragments, dicentric chromosomes, and aneuploidy. In addition, the $\mathrm{T}$ lymphocytes have an elevated frequency of translocations with break points mapping to the T-cell antigen receptor genes and the Ig heavy chain genes (reviewed in [85]). Following exposure to ionizing radiation or radiomimetic agents, cells from AT patients have an increased frequency of chromosomal aberrations compared to normal cells $[60,84,85,86]$. In vivo, we have reported that Atmdeficient mice have an increased frequency of spontaneous HR [87]. In comparison, Turker et al demonstrated that, in the same mouse background, a deficiency in Atm did not result in an increased frequency of mutations [88], thus indicating that HR plays a more important role in the etiology of the AT.

ATM is generally thought to be important in activating p53 in response to the DNA damage $[89,90]$. Recent reports have highlighted the multifunctional aspect of ATM, including that it phosphorylates BRCA1 [91, 92] and NBS $[93,94,95,96]$ following irradiation. In addition, there have been several reports linking ATM, through c-ABL1, to the HR protein RAD51 [97, 98, 99, 100]. Again, as with p53, how do these interactions relate to the HR is not fully understood, but it is an area of intense research.

A mutation in the BRCA1 gene is estimated to confer a $70 \%$ risk of breast cancer by age 70 (reviewed in [101]). There have been numerous studies examining the frequency of breast cancers. From these studies, it is evident that mutations in the BRCA1 and BRCA2 genes result in an early onset of cancer and are responsible for a high percentage of premenopausal breast cancers ( $12 \%$ to $28 \%$ ). The percentage depends on the prevalence of founder mutations within the population examined $[102,103,104,105,106,107,108$, $109,110]$, the incidence of nonfamilial breast cancers tend to occur at a later age. Inactivation of $B R C A 1$ or $B R C A 2$ confers genetic instability such as aneuploidy and chromosomal rearrangements $[111,112,113,114,115,116]$. In addition, both BRCA1 and BRCA2 play a role in HR, in the absence of either protein, HR repair of double-stranded breaks is defective [117]. It has been reported that BRCA1, BRCA2, and RAD51 form foci in the nucleus following the DNA damage $[118,119,120]$ in an ATM-dependent manner [92].

RAD51, RAD52, and RAD54 are components of the RAD52 epistasis group $[12,121,122]$, homologues of the genes defined in yeast to be necessary for an HR reaction. In vitro, it has been shown that RAD52 binds single-stranded tails at the sites of resected DSBs [123] as well as capping the exposed terminal nucleotide [124]. Both RAD51 and RAD54 form foci following the DNA damage [125]. In addition, the loss of RAD54 leads to recombinational deficiencies and DSB repair defects $[126,127]$. The absence of RAD51 results in an accumulation of chromosomal abnormalities and cell death [128]. Both RAD51 and RAD54 have been shown to mediate sister chromatid exchange [129] and both form foci following exposure to ionising radiation, the kinetics of these foci are altered in ATM-deficient cells $[130,131]$. How do the observed foci relate to the $\mathrm{HR}$, is still unclear, but it does appear that BRCA1 is a component of several DNA damage response mechanisms [132] and may be responsible for activating HR in certain circumstances.

The genes mutated in Bloom's and Werner's syndromes, $B L M$ and $W R N$, respectively, are highly homologous to RecQ helicase $[133,134]$, and were postulated to be involved in recombination. Cells from Bloom's syndrome patients show a high frequency of sister chromatid exchanges, hyper recombination, and chromosomal breakage. Patients with Bloom's 
syndrome also show a greatly elevated predisposition to cancer of the sites and types that affect the general population [135]. Similarly, cells from Werner's syndrome patients show a 50 -fold elevation in mutation rate, with the predominant form of mutations being gross DNA deletions [63]. The Werner syndrome patients age prematurely and show features like early onset of cataracts, generalized hair loss, loss of skin elasticity, osteoporosis, atherosclerosis, and short stature [136], they also often develop nonepithelial tumours and, to a lesser extent, leukemia, and carcinomata. These cancer prone diseases have in common a defect in genomic stability. Notably, both BLM and WRN have now been associated with processing the structures associated with stalled replication forks $[137,138]$, which may explain the observed phenotypes.

Fanconi's anemia (FA) is an autosomal recessive genetic disorder characterised clinically by progressive bone marrow failure, skeletal deformities, and a predisposition to neoplasia [139, 140]. Patient cells manifest an extreme chromosomal instability and hypersensitivity to polyfunctional alkylating agents. Most interstingly, cells from FA patients as well as cell extracts show a much elevated frequency of HR measured with plasmid constructs [141].

Although the AT has been identified to be the result of a mutation in the ATM gene, two other mutations result in syndromes that were originally mistaken to be AT. These variants of AT are caused by mutations in NBS (the syndrome is presently called Nijmegen breakage syndrome) [142] and in MRE11A [143], and present similar phenotypes, including genetic instability. NBS, MRE11, and RAD50 form a complex that NBS modulates once it is phosphorylated by the ATM in response to the DNA damage [93, 94, 95]. In yeast, it has been shown that RAD50 and MRE11 are involved in NHEJ [144, 145, 146], a mechanism that can repair double strand breaks and competes with HR. Assuming that the mammalian homologues of these genes are also involved in NHEJ, it seems plausible that a deficiency in ATM also results in a slight deficiency in NHEJ. Therefore, the damage would be channelled into HR as an alternative pathway, possibly explaining the hyper recombination phenotype that we found in Atm-deficient mice [87]. Most recently, it has been demonstrated that the WRN interacts with the Ku heterodimer [147], the complex thought to bind double strand break ends at the initiation of NHEJ $[12,148,149,150]$. Thus, in a fashion similar to AT, a WRN deficiency may lead to an increased frequency of HR by default.

\section{Susceptibility of proliferating cells to homologous recombination}

Actively dividing cells are thought to be the most prone to developing cancer. Mitogenesis has been proposed to be an important contributor to carcinogenesis [151,152] as evidenced by a higher risk for cancer after tissue regeneration. Furthermore, chemical carcinogenesis and transformation are most efficient if the target cells are treated just prior to or during the S phase $[153,154]$.
Using yeast to investigate the effect of the cell cycle arrest on the induction of deletions mediated by HR by different carcinogens, it was found that only DNA double strand breaks induce homologous deletion recombination in arrested cells, other forms of DNA damage such as DNA single strand breaks, UV lesions, as well as exposure to alkylating agents need DNA replication to induce homologous deletion recombination $[155,156]$.

As mentioned earlier, HR events are mediated by the RAD52 epistasis group. It is interesting to note that the protein and mRNA levels of this group tend to correlate with cell proliferation. For example, it has been reported that RAD51 expression is the highest in intestinal and uterine epithelia [157], which are highly proliferative. RAD51 has also proven to be essential in early mouse development $[158,159]$, a time of massive cellular proliferation. Consistent with the correlation with cell proliferation, both RAD51 and RAD54 are maximally transcribed in the $S$ phase, during DNA synthesis $[157,160,161,162]$. These observations are suggestive of a function for HR in proliferating cells, especially in combination with the damage inducibility of HR in proliferating cells. Takata et al [163], using chicken DT40 cells, demonstrated the involvement of NHEJ in G1 to early S phase, with HR functioning more in late $S$ phase to G2. The role of replication was further demonstrated by Saintigny et al [164], who demonstrated that HR is increased in late S phase, only after the RAD51 foci formation. These studies strongly support the recent proposal that HR performs a special function during replication, namely, in resolving stalled replication forks $[165,166,167,168]$. Altogether, it appears that HR is a common feature of the normal cell and may be especially harnessed by highly proliferative cancer cells.

\section{CONCLUSIONS}

In conclusion, we have presented a body of evidence that HR can play a role in different stages of carcinogenesis. While HR may contribute to the initial steps of carcinogenesis, we believe that HR functions mostly as a secondary or subsequent step in tumor progression. If genomic rearrangements and deletion events were the cause of a portion of the cancers, it might also be expected that certain carcinogens would increase the frequency of genome rearrangements. This has in fact been elegantly demonstrated in yeast $[58,169,170]$, in human cells [22], as well as in vivo in mice [21, 23, 59]. With a wide variety of carcinogenic agents able to induce $H R$, it is easy to suggest that the normal day-to-day exposure to a variety of environmental and endogenous damages will also increase the frequency of HR. As can be observed in those patients who have an up regulated level of $\mathrm{HR}$, an increased frequency of HR events can be highly deleterious. In addition, the sensitivity of proliferating cells to HR is highly correlative with proliferating cells being more prone to cancer and fits with current models of replication/recombination. Finally, the HR is likely to play a major role in producing the observed heterogeneity in many tumours. All in all, HR may be much more prevalent during carcinogenesis than previously considered. 


\section{ACKNOWLEDGMENTS}

This work was supported by grants from the American Cancer Society No. RPG-95-076-04-MGO and the National Institute of Environmental Health Sciences, NIH, RO1 grant No ES09519 and KO2 award ES00299 (to R.H. Schiestl), and NIH RCDA Award No. F32GM19147 (to A.J.R. Bishop).

\section{REFERENCES}

[1] Todd R, Wong DT. Oncogenes. Anticancer Res. 1999;19(6A):4729-4746.

[2] Macleod K. Tumor suppressor genes. Curr Opin Genet Dev. 2000;10(1):81-93.

[3] Knudson AG. Antioncogenes and human cancer. Proc Natl Acad Sci USA. 1993;90(23):10914-10921.

[4] Thein SL, Jeffreys AJ, Gooi HC, et al. Detection of somatic changes in human cancer DNA by DNA fingerprint analysis. Br J Cancer. 1987;55(4):353-356.

[5] Greller LD, Tobin FL, Poste G. Tumor heterogeneity and progression: conceptual foundations for modeling. Invasion Metastasis. 1996;16(4-5):177-208.

[6] Heppner GH, Miller FR. The cellular basis of tumor progression. Int Rev Cytol. November 1998;177:1-56.

[7] Loeb KR, Loeb LA. Significance of multiple mutations in cancer. Carcinogenesis. 2000;21(3):379-385.

[8] Coleman WB, Tsongalis GJ. The role of genomic instability in human carcinogenesis. Anticancer Res. 1999;19(6A):4645-4664.

[9] Rasnick D, Duesberg PH. How aneuploidy affects metabolic control and causes cancer. Biochem J. 1999;340(Pt 3):621-630.

[10] Schmutte C, Fishel R. Genomic instability: first step to carcinogenesis. Anticancer Res. 1999;19(6A):46654696.

[11] Vessey CJ, Norbury CJ, Hickson ID. Genetic disorders associated with cancer predisposition and genomic instability. Prog Nucleic Acid Res Mol Biol. October 1999;63:189-221.

[12] Kanaar R, Hoeijmakers JH, van Gent DC. Molecular mechanisms of DNA double strand break repair. Trends Cell Biol. 1998;8(12):483-489.

[13] Lengauer C, Kinzler KW, Vogelstein B. Genetic instabilities in human cancers. Nature. 1998;396(6712):643-649.

[14] Mitchell MB. Further evidence of aberrant recombination in Neurospora. Proc Natl Acad Sci USA. 1955;41(11):935-937.

[15] Liang F, Han M, Romanienko PJ, Jasin M. Homologydirected repair is a major double-strand break repair pathway in mammalian cells. Proc Natl Acad Sci USA. 1998;95(9):5172-5177.

[16] Johnson RD, Jasin M. Sister chromatid gene conversion is a prominent double-strand break repair pathway in mammalian cells. EMBO J. 2000;19(13):33983407.

[17] Moynahan ME, Jasin M. Loss of heterozygosity in- duced by a chromosomal double-strand break. Proc Natl Acad Sci USA. 1997;94(17):8988-8993.

[18] Richardson C, Moynahan ME, Jasin M. Doublestrand break repair by interchromosomal recombination: suppression of chromosomal translocations. Genes Dev. 1998;12(24):3831-3842.

[19] Gondo Y, Gardner JM, Nakatsu Y, et al. Highfrequency genetic reversion mediated by a DNA duplication: the mouse pink-eyed unstable mutation. Proc Natl Acad Sci USA. 1993;90(1):297-301.

[20] Schiestl RH, Gietz RD, Hastings PJ, Wintersberger U. Interchromosomal and intrachromosomal recombination in rad 18 mutants of Saccharomyces cerevisiae. Mol Gen Genet. 1990;222(1):25-32.

[21] Schiestl RH, Khogali F, Carls N. Reversion of the mouse pink-eyed unstable mutation induced by low doses of X-rays. Science. 1994;266(5190):1573-1576.

[22] Aubrecht J, Rugo R, Schiestl RH. Carcinogens induce intrachromosomal recombination in human cells. Carcinogenesis. 1995;16(11):2841-2846.

[23] Schiestl RH, Aubrecht J, Khogali F, Carls N. Carcinogens induce reversion of the mouse pink-eyed unstable mutation. Proc Natl Acad Sci USA. 1997;94(9):45764581.

[24] Winkler H. Die Konversion der Gene. Jena: Fisher Verlag; 1930.

[25] Mitchell MB. Aberrant recombinations of pyridoxine mutants of Neurospora. Proc Natl Acad Sci USA. 1955(4);41:215.

[26] Roman H. Studies of gene mutation in Saccharomyces. Cold Sring Harb. Symp. Quant. Biol. 1956;21:175-185.

[27] Fogel S, Mortimer RK. Fidelity of meiotic gene conversion in yeast. Mol Gen Genet. 1970;109(2):177-185.

[28] Mitelman F. Chromosomes, genes, and cancer [editorial]. CA Cancer J Clin. 1994;44(3):133-135.

[29] Tlsty TD. Genomic instability and its role in neoplasia. Curr Top Microbiol Immunol. January 1997;221:37-46.

[30] Aardema MJ, Albertini S, Arni P, et al. Aneuploidy: a report of an ECETOC task force. Mutat Res. 1998;410(1):3-79.

[31] Jeffs AR, Benjes SM, Smith TL, Sowerby SJ, Morris $\mathrm{CM}$. The $\mathrm{BCR}$ gene recombines preferentially with Alu elements in complex BCR-ABL translocations of chronic myeloid leukaemia. Hum Mol Genet. 1998;7(5):767-776.

[32] Martinelli G, Terragna C, Amabile M, et al. Alu and translisin recognition site sequences flanking translocation sites in a novel type of chimeric bcr-abl transcript suggest a possible general mechanism for bcrabl breakpoints. Haematologica. 2000;85(1):40-46.

[33] Kokoska RJ, Stefanovic L, Tran HT, Resnick MA, Gordenin DA, Petes TD. Destabilization of yeast microand minisatellite DNA sequences by mutations affecting a nuclease involved in Okazaki fragment processing ( $\mathrm{rad} 27)$ and DNA polymerase delta (pol3-t). Mol Cell Biol. 1998;18(5):2779-2788.

[34] Sia EA, Kokoska RJ, Dominska M, Greenwell P, Petes TD. Microsatellite instability in yeast: dependence on 
repeat unit size and DNA mismatch repair genes. $\mathrm{Mol}$ Cell Biol. 1997;17(5):2851-2858.

[35] Schlotterer C, Tautz D. Slippage synthesis of simple sequence DNA. Nucleic Acids Res. 1992;20(2):211-215.

[36] Levinson G, Gutman GA. High frequencies of short frameshifts in poly-CA/TG tandem repeats borne by bacteriophage M13 in Escherichia coli K-12. Nucleic Acids Res. 1987;15(13):5323-5338.

[37] Levinson G, Gutman GA. Slipped-strand mispairing: a major mechanism for DNA sequence evolution. $\mathrm{Mol}$ Biol Evol. 1987;4(3):203-221.

[38] Ionov Y, Peinado MA, Malkhosyan S, Shibata D, Perucho $\mathrm{M}$. Ubiquitous somatic mutations in simple repeated sequences reveal a new mechanism for colonic carcinogenesis. Nature. 1993;363(6429):558-561.

[39] Thibodeau SN, Bren G, Schaid D. Microsatellite instability in cancer of the proximal colon. Science. 1993;260(5109):816-819.

[40] Aaltonen LA, Peltomaki P, Leach FS, et al. Clues to the pathogenesis of familial colorectal cancer. Science. 1993;260(5109):812-816.

[41] Parsons R, Li GM, Longley MJ, et al. Hypermutability and mismatch repair deficiency in RER+ tumor cells. Cell. 1993;75(6):1227-1236.

[42] Yen PH, Li XM, Tsai SP, Johnson C, Mohandas T, Shapiro LJ. Frequent deletions of the human X chromosome distal short arm result from recombination between low copy repetitive elements. Cell. 1990;61(4):603-610.

[43] Ballabio A, Bardoni B, Guioli S, Basler E, Camerino G. Two families of low-copy-number repeats are interspersed on Xp22.3: implications for the high frequency of deletions in this region. Genomics. 1990;8(2):263270.

[44] Pentao L, Wise CA, Chinault AC, Patel PI, Lupski JR. Charcot-Marie-Tooth type 1A duplication appears to arise from recombination at repeat sequences flanking the 1.5 Mb monomer unit. Nat Genet. 1992;2(4):292300.

[45] Chance PF, Alderson MK, Leppig KA, et al. DNA deletion associated with hereditary neuropathy with liability to pressure palsies. Cell. 1993;72(1):143-151.

[46] Nelis E, Van Broeckhoven C, De Jonghe P, et al. Estimation of the mutation frequencies in Charcot-MarieTooth disease type 1 and hereditary neuropathy with liability to pressure palsies: a European collaborative study. Eur J Hum Genet. 1996;4(1):25-33.

[47] Ledbetter DH, Riccardi VM, Airhart SD, Strobel RJ, Keenan BS, Crawford JD. Deletions of chromosome 15 as a cause of the Prader-Willi syndrome. N Engl J Med. 1981;304(6):325-329.

[48] de la Chapelle A, Herva R, Koivisto M, Aula P. A deletion in chromosome 22 can cause DiGeorge syndrome. Hum Genet. 1981;57(3):253-256.

[49] Lehrman MA, Schneider WJ, Sudhof TC, Brown MS, Goldstein JL, Russell DW. Mutation in LDL receptor: Alu-Alu recombination deletes exons encoding transmembrane and cytoplasmic domains. Science.
1985;227(4683):140-146.

[50] Haber JE. Exploring the pathways of homologous recombination. Curr Opin Cell Biol. 1992;4(3):401-412.

[51] Michel B, Flores MJ, Viguera E, Grompone G, Seigneur M, Bidnenko V. Rescue of arrested replication forks by homologous recombination. Proc Natl Acad Sci USA. 2001;98(15):8181-8188.

[52] Chen C, Kolodner RD. Gross chromosomal rearrangements in Saccharomyces cerevisiae replication and recombination defective mutants. Nat Genet. 1999;23(1):81-85.

[53] Gebow D, Miselis N, Liber HL. Homologous and nonhomologous recombination resulting in deletion: effects of p53 status, microhomology, and repetitive DNA length and orientation. Mol Cell Biol. 2000;20(11):4028-4035.

[54] Hoogendijk JE, Hensels GW, Gabreels-Festen AA, et al. De-novo mutation in hereditary motor and sensory neuropathy type I. Lancet. 1992;339(8801):10811082.

[55] Wise CA, Garcia CA, Davis SN, et al. Molecular analyses of unrelated Charcot-Marie-Tooth (CMT) disease patients suggest a high frequency of the CMTIA duplication. Am J Hum Genet. 1993;53(4):853863.

[56] Schichman SA, Caligiuri MA, Strout MP, et al. ALL1 tandem duplication in acute myeloid leukemia with a normal karyotype involves homologous recombination between Alu elements. Cancer Res. 1994;54(16):4277-4280.

[57] Schiestl RH, Igarashi S, Hastings PJ. Analysis of the mechanism for reversion of a disrupted gene. Genetics. 1988;119(2):237-247.

[58] Schiestl RH. Nonmutagenic carcinogens induce intrachromosomal recombination in yeast. Nature. 1989;337(6204):285-288.

[59] Schiestl RH, Aubrecht J, Yap WY, Kandikonda S, Sidhom S. Polychlorinated biphenyls and 2,3,7,8tetrachlorodibenzo-p-dioxin induce intrachromosomal recombination in vitro and in vivo. Cancer Res. 1997;57(19):4378-4383.

[60] Meyn MS. High spontaneous intrachromosomal recombination rates in ataxia-telangiectasia. Science. 1993;260(5112):1327-1330.

[61] Livingstone LR, White A, Sprouse J, Livanos E, Jacks T, Tlsty TD. Altered cell cycle arrest and gene amplification potential accompany loss of wild-type p53. Cell. 1992;70(6):923-935.

[62] German J. Bloom's syndrome. Dermatol Clin. 1995;13(1):7-18.

[63] Fukuchi K, Martin GM, Monnat RJ Jr. Mutator phenotype of Werner syndrome is characterized by extensive deletions. Proc Natl Acad Sci USA. 1989;86(15):58935897 [published erratum appears in Proc Natl Acad Sci USA. October 1989;86(20):7994].

[64] Ellis NA. Mutation-causing mutations [news]. Nature. 1996;381(6578):110-111.

[65] Strong LC, Williams WR, Tainsky MA. The Li- 
Fraumeni syndrome: from clinical epidemiology to molecular genetics. Am J Epidemiol. 1992;135(2):190199.

[66] Hisada M, Garber JE, Fung CY, Fraumeni JF Jr, Li FP. Multiple primary cancers in families with Li-Fraumeni syndrome. J Natl Cancer Inst. 1998;90(8):606-611.

[67] Levine AJ. p53, the cellular gatekeeper for growth and division. Cell. 1997;88(3):323-331.

[68] Agarwal ML, Taylor WR, Chernov MV, Chernova OB, Stark GR. The p53 network. J Biol Chem. 1998;273(1):1-4.

[69] Wang XW, Yeh H, Schaeffer L, et al. p53 modulation of TFIIH-associated nucleotide excision repair activity. Nat Genet. 1995;10(2):188-195.

[70] Offer H, Wolkowicz R, Matas D, Blumenstein S, Livneh Z, Rotter V. Direct involvement of p53 in the base excision repair pathway of the DNA repair machinery. FEBS Lett. 1999;450(3):197-204.

[71] Sturzbecher HW, Donzelmann B, Henning W, Knippschild U, Buchhop S. p53 is linked directly to homologous recombination processes via RAD51/RecA protein interaction. EMBO J. 1996;15(8):1992-2002.

[72] Willers H, McCarthy EE, Wu B, et al. Dissociation of p53-mediated suppression of homologous recombination from G1/S cell cycle checkpoint control. Oncogene. 2000;19(5):632-639.

[73] Gebow D, Miselis N, Liber HL. Homologous and nonhomologous recombination resulting in deletion: effects of p53 status, microhomology, and repetitive DNA length and orientation. Mol Cell Biol. 2000;20(11):4028-4035.

[74] Yin Y, Tainsky MA, Bischoff FZ, Strong LC, Wahl GM. Wild-type p53 restores cell cycle control and inhibits gene amplification in cells with mutant p53 alleles. Cell. 1992;70(6):937-948.

[75] Harvey M, Sands AT, Weiss RS, et al. In vitro growth characteristics of embryo fibroblasts isolated from p53-deficient mice. Oncogene. 1993;8(9):2457-2467.

[76] Purdie CA, Harrison DJ, Peter A, et al. Tumour incidence, spectrum and ploidy in mice with a large deletion in the p53 gene. Oncogene. 1994;9(2):603-609.

[77] Donehower LA, Godley LA, Aldaz CM, et al. Deficiency of p53 accelerates mammary tumorigenesis in Wnt-1 transgenic mice and promotes chromosomal instability. Genes Dev. 1995;9(7):882-895.

[78] Buchhop S, Gibson MK, Wang XW, Wagner P, Sturzbecher HW, Harris CC. Interaction of p53 with the human Rad51 protein. Nucleic Acids Res. 1997;25(19):3868-3874.

[79] Bertrand P, Rouillard D, Boulet A, Levalois C, Soussi $\mathrm{T}$, Lopez BS. Increase of spontaneous intrachromosomal homologous recombination in mammalian cells expressing a mutant p53 protein. Oncogene. 1997;14(9):1117-1122.

[80] Mekeel KL, Tang W, Kachnic LA, Luo CM, DeFrank JS, Powell SN. Inactivation of p53 results in high rates of homologous recombination. Oncogene. 1997;14(15):1847-1857.
[81] Aubrecht J, Secretan MB, Bishop AJ, Schiestl RH. Involvement of p53 in X-ray induced intrachromosomal recombination in mice. Carcinogenesis. 1999;20(12):2229-2236.

[82] Easton DF. Cancer risks in A-T heterozygotes. Int J Radiat Biol. 1994;66(suppl 6):S177-S182.

[83] Angele S, Hall J. The ATM gene and breast cancer: is it really a risk factor? Mutat Res. 2000;462(2-3):167-178.

[84] Cohen MM, Levy HP. Chromosome instability syndromes. Adv Hum Genet. July 1989;18:43-149.

[85] Kojis TL, Gatti RA, Sparkes RS. The cytogenetics of ataxia telangiectasia. Cancer Genet Cytogenet. 1991;56(2):143-156.

[86] Luo CM, Tang W, Mekeel KL, DeFrank JS, Anne PR, Powell SN. High frequency and error-prone DNA recombination in ataxia telangiectasia cell lines. J Biol Chem. 1996;271(8):4497-4503.

[87] Bishop AJ, Barlow C, Wynshaw-Boris AJ, Schiestl RH. Atm deficiency causes an increased frequency of intrachromosomal homologous recombination in mice. Cancer Res. 2000;60(2):395-399.

[88] Turker MS, Gage BM, Rose JA, et al. Solid tissues removed from ATM homozygous deficient mice do not exhibit a mutator phenotype for second-step autosomal mutations. Cancer Res. 1999;59(19):4781-4783.

[89] Siliciano JD, Canman CE, Taya Y, Sakaguchi K, Appella E, Kastan MB. DNA damage induces phosphorylation of the amino terminus of p53. Genes Dev. 1997;11(24):3471-3481.

[90] Shieh SY, Ikeda M, Taya Y, Prives C. DNA damageinduced phosphorylation of p53 alleviates inhibition by MDM2. Cell. 1997;91(3):325-334.

[91] Scully R, Chen J, Ochs RL, et al. Dynamic changes of BRCA1 subnuclear location and phosphorylation state are initiated by DNA damage. Cell. 1997;90(3):425435.

[92] Cortez D, Wang Y, Qin J, Elledge SJ. Requirement of ATM-dependent phosphorylation of brcal in the DNA damage response to double-strand breaks. Science. 1999;286(5442):1162-1166.

[93] Lim DS, Kim ST, Xu B, et al. ATM phosphorylates p95/nbs1 in an S-phase checkpoint pathway. Nature. 2000;404(6778):613-617.

[94] Gatei M, Young D, Cerosaletti KM, et al. ATMdependent phosphorylation of nibrin in response to radiation exposure. Nat Genet. 2000;25(1):115-119.

[95] Wu X, Ranganathan V, Weisman DS, et al. ATM phosphorylation of Nijmegen breakage syndrome protein is required in a DNA damage response. Nature. 2000;405(6785):477-482.

[96] Zhao S, Weng YC, Yuan SS, et al. Functional link between ataxia-telangiectasia and Nijmegen breakage syndrome gene products. Nature. 2000;405(6785):473-477.

[97] Baskaran R, Wood LD, Whitaker LL, et al. Ataxia telangiectasia mutant protein activates c-Abl tyrosine kinase in response to ionizing radiation. Nature. 1997;387(6632):516-519. 
[98] Shafman T, Khanna KK, Kedar P, et al. Interaction between ATM protein and c-Abl in response to DNA damage. Nature. 1997;387(6632):520-523.

[99] Yuan ZM, Huang Y, Ishiko T, et al. Regulation of Rad51 function by c-Abl in response to DNA damage. J Biol Chem. 1998;273(7):3799-3802.

[100] Chen G, Yuan SS, Liu W, et al. Radiation-induced assembly of Rad51 and Rad52 recombination complex requires ATM and c-Abl. J Biol Chem. 1999;274(18):12748-12752.

[101] Rebbeck TR. Inherited predisposition and breast cancer: modifiers of BRCA1/2-associated breast cancer risk. Environ Mol Mutagen. 2002;39(2-3):228-234.

[102] Tonin P, Weber B, Offit K, et al. Frequency of recurrent BRCA1 and BRCA2 mutations in Ashkenazi Jewish breast cancer families. Nat Med. 1996;2(11):11791183.

[103] Nedelcu R, Liede A, Aube J, et al. BRCA mutations in Italian breast/ovarian cancer families. Eur J Hum Genet. 2002;10(2):150-152.

[104] Liede A, Jack E, Hegele RA, Narod SA. A BRCA1 mutation in Native North American families. Hum Mutat. 2002;19(4):460.

[105] De Leon Matsuda ML, Liede A, Kwan E, et al. BRCA1 and BRCA2 mutations among breast cancer patients from the Philippines. Int J Cancer. 2002;98(4):596603.

[106] Malone KE, Daling JR, Neal C, et al. Frequency of BRCA1/BRCA2 mutations in a population-based sample of young breast carcinoma cases. Cancer. 2000;88(6):1393-1402.

[107] Malone KE, Daling JR, Thompson JD, O'Brien CA, Francisco LV, Ostrander EA. BRCA1 mutations and breast cancer in the general population: analyses in women before age 35 years and in women before age 45 years with first-degree family history. JAMA. 1998;279(12):922-929.

[108] Langston AA, Malone KE, Thompson JD, Daling JR, Ostrander EA. BRCA1 mutations in a populationbased sample of young women with breast cancer. $N$ Engl J Med. 1996;334(3):137-142.

[109] Peto J, Collins N, Barfoot R, et al. Prevalence of BRCA1 and BRCA2 gene mutations in patients with early-onset breast cancer. J Natl Cancer Inst. 1999;91(11):943-949.

[110] Warner E, Foulkes W, Goodwin P, et al. Prevalence and penetrance of BRCA1 and BRCA2 gene mutations in unselected Ashkenazi Jewish women with breast cancer. J Natl Cancer Inst. 1999;91(14):1241-1247.

[111] Xu X, Weaver Z, Linke SP, et al. Centrosome amplification and a defective G2-M cell cycle checkpoint induce genetic instability in BRCA1 exon 11 isoform-deficient cells. Mol Cell. 1999;3(3):389-395.

[112] Tirkkonen M, Johannsson O, Agnarsson BA, et al. Distinct somatic genetic changes associated with tumor progression in carriers of BRCA1 and BRCA2 germline mutations. Cancer Res. 1997;57(7):1222-1227.

[113] Gretarsdottir S, Thorlacius S, Valgardsdottir R, et al.
BRCA2 and p53 mutations in primary breast cancer in relation to genetic instability. Cancer Res. 1998;58(5):859-862.

[114] Patel KJ, Yu VP, Lee H, et al. Involvement of Brca2 in DNA repair. Mol Cell. 1998;1(3):347-357.

[115] Tutt A, Gabriel A, Bertwistle D, et al. Absence of Brca2 causes genome instability by chromosome breakage and loss associated with centrosome amplification. Curr Biol. 1999;9(19):1107-1110.

[116] Ban S, Shinohara T, Hirai Y, Moritaku Y, Cologne JB, MacPhee DG. Chromosomal instability in BRCA1or BRCA2-defective human cancer cells detected by spontaneous micronucleus assay. Mutat Res. 2001;474(1-2):15-23.

[117] Moynahan ME, Chiu JW, Koller BH, Jasin M. Brca1 controls homology-directed DNA repair. Mol Cell. 1999;4(4):511-518.

[118] Haaf T, Golub EI, Reddy G, Radding CM, Ward DC. Nuclear foci of mammalian Rad51 recombination protein in somatic cells after DNA damage and its localization in synaptonemal complexes. Proc Natl Acad Sci USA. 1995;92(6):2298-2302.

[119] Moynahan ME, Pierce AJ, Jasin M. BRCA2 is required for homology-directed repair of chromosomal breaks. Mol Cell. 2001;7(2):263-272.

[120] Tutt A, Bertwistle D, Valentine J, et al. Mutation in Brca2 stimulates error-prone homology-directed repair of DNA double-strand breaks occurring between repeated sequences. EMBO J. 2001;20(17):4704-4716.

[121] Petrini JH, Bressan DA, Yao MS. The RAD52 epistasis group in mammalian double strand break repair. Semin Immunol. 1997;9(3):181-188.

[122] Baumann P, West SC. Role of the human RAD51 protein in homologous recombination and double-stranded-break repair. Trends Biochem Sci. 1998;23(7):247-251.

[123] Van Dyck E, Stasiak AZ, Stasiak A, West SC. Binding of double-strand breaks in DNA by human Rad52 protein. Nature. 1999;398(6729):728-731.

[124] Parsons CA, Baumann P, Van Dyck E, West SC. Precise binding of single-stranded DNA termini by human RAD52 protein. EMBO J. 2000;19(15):4175-4181.

[125] Tan TL, Essers J, Citterio E, et al. Mouse Rad54 affects DNA conformation and DNA-damage-induced Rad51 foci formation. Curr Biol. 1999;9(6):325-328.

[126] Bezzubova O, Silbergleit A, Yamaguchi-Iwai Y, Takeda S, Buerstedde JM. Reduced X-ray resistance and homologous recombination frequencies in a RAD54/- mutant of the chicken DT40 cell line. Cell. 1997;89(2):185-193.

[127] Essers J, Hendriks RW, Swagemakers SM, et al. Disruption of mouse RAD54 reduces ionizing radiation resistance and homologous recombination. Cell. 1997;89(2):195-204.

[128] Sonoda E, Sasaki MS, Buerstedde JM, et al. Rad51deficient vertebrate cells accumulate chromosomal breaks prior to cell death. EMBO J. 1998;17(2):598608. 
[129] Sonoda E, Sasaki MS, Morrison C, Yamaguchi-Iwai Y, Takata M, Takeda S. Sister chromatid exchanges are mediated by homologous recombination in vertebrate cells. Mol Cell Biol. 1999;19(7):5166-5169.

[130] Maser RS, Monsen KJ, Nelms BE, Petrini JH. hMre11 and hRad50 nuclear foci are induced during the normal cellular response to DNA double-strand breaks. Mol Cell Biol. 1997;17(10):6087-6096.

[131] Morrison C, Sonoda E, Takao N, Shinohara A, Yamamoto K, Takeda S. The controlling role of ATM in homologous recombinational repair of DNA damage. EMBO J. 2000;19(3):463-471.

[132] Wang Y, Cortez D, Yazdi P, Neff N, Elledge SJ, Qin J. BASC, a super complex of BRCA1-associated proteins involved in the recognition and repair of aberrant DNA structures. Genes Dev. 2000;14(8):927-939.

[133] Ellis NA, Groden J, Ye TZ, et al. The Bloom's syndrome gene product is homologous to RecQ helicases. Cell. 1995;83(4):655-666.

[134] Yu CE, Oshima J, Fu YH, Wijsman EM, et al. Positional cloning of the Werner's syndrome gene. Science. 1996;272(5259):258-262.

[135] German J. Bloom syndrome: a mendelian prototype of somatic mutational disease. Medicine (Baltimore). 1993;72(6):393-406.

[136] Epstein CJ, Martin GM, Schultz AL, Motulsky AG. Werner's syndrome a review of its symptomatology, natural history, pathologic features, genetics and relationship to the natural aging process. Medicine (Baltimore). 1966;45(3):177-221.

[137] Pichierri P, Franchitto A, Mosesso P, Palitti F. Werner's syndrome protein is required for correct recovery after replication arrest and DNA damage induced in S-phase of cell cycle. Mol Biol Cell. 2001;12(8):24122421.

[138] Franchitto A, Pichierri P. Bloom's syndrome protein is required for correct relocalization of RAD50/MRE11/NBS1 complex after replication fork arrest. J Cell Biol. 2002;157(1):19-30.

[139] Garcia-Higuera I, Kuang Y, D’Andrea AD. The molecular and cellular biology of Fanconi anemia. Curr Opin Hematol. 1999;6(2):83-88.

[140] Digweed M. Molecular basis of Fanconi's anemia. Klin Padiatr. 1999;211(4):192-197.

[141] Thyagarajan B, Campbell C. Elevated homologous recombination activity in fanconi anemia fibroblasts. $J$ Biol Chem. 1997;272(37):23328-23333.

[142] Carney JP, Maser RS, Olivares H, et al. The hMre11/hRad50 protein complex and Nijmegen breakage syndrome: linkage of double-strand break repair to the cellular DNA damage response. Cell. 1998;93(3):477-486.

[143] Stewart GS, Maser RS, Stankovic T, et al. The DNA double-strand break repair gene hMRE11 is mutated in individuals with an ataxia-telangiectasia-like disorder. Cell. 1999;99(6):577-587.

[144] Schiestl RH, Zhu J, Petes TD. Effect of mutations in genes affecting homologous recombination on re- striction enzyme-mediated and illegitimate recombination in Saccharomyces cerevisiae. Mol Cell Biol. 1994;14(7):4493-4500.

[145] Milne GT, Jin S, Shannon KB, Weaver DT. Mutations in two Ku homologs define a DNA end-joining repair pathway in Saccharomyces cerevisiae. Mol Cell Biol. 1996;16(8):4189-4198.

[146] Boulton SJ, Jackson SP. Components of the $\mathrm{Ku}-$ dependent non-homologous end-joining pathway are involved in telomeric length maintenance and telomeric silencing. EMBO J. 1998;17(6):1819-1828.

[147] Li B, Comai L. Functional interaction between $\mathrm{Ku}$ and the werner syndrome protein in DNA end processing. J Biol Chem. 2000;275(37):28349-28352.

[148] Ramsden DA, Gellert M. Ku protein stimulates DNA end joining by mammalian DNA ligases: a direct role for $\mathrm{Ku}$ in repair of DNA double-strand breaks. EMBO J. 1998;17(2):609-614.

[149] Lieber MR. Warner-Lambert/Parke-Davis Award Lecture. Pathological and physiological double-strand breaks: roles in cancer, aging, and the immune system. Am J Pathol. 1998;153(5):1323-1332.

[150] Critchlow SE, Jackson SP. DNA end-joining: from yeast to man. Trends Biochem Sci. 1998;23(10):394398.

[151] Ames BN, Gold LS. Too many rodent carcinogens: mitogenesis increases mutagenesis. Science. 1990;249(4972):970-971 [published erratum appears in Science. September 28, 1990;249(4976):1487].

[152] Ames BN, Gold LS. Chemical carcinogenesis: too many rodent carcinogens. Proc Natl Acad Sci USA. 1990;87(19):7772-7776.

[153] Friedberg EC, Walker GC, Siede W. DNA Repair and Mutagenesis. Washington, DC: American Society for Microbiology; 1995.

[154] Kaufmann WK, Paules RS. DNA damage and cell cycle checkpoints. FASEB J. 1996;10(2):238-247.

[155] Galli A, Schiestl RH. Effects of DNA double-strand and single-strand breaks on intrachromosomal recombination events in cell-cycle-arrested yeast cells. Genetics. 1998;149(3):1235-1250.

[156] Galli A, Schiestl RH. Cell division transforms mutagenic lesions into deletion-recombinagenic lesions in yeast cells. Mutat Res. 1999;429(1):13-26.

[157] Yamamoto A, Taki T, Yagi $H$, et al. Cell cycledependent expression of the mouse Rad51 gene in proliferating cells. Mol Gen Genet. 1996;251(1):1-12.

[158] Lim DS, Hasty P. A mutation in mouse rad51 results in an early embryonic lethal that is suppressed by a mutation in p53. Mol Cell Biol. 1996;16(12):7133-7143.

[159] Tsuzuki T, Fujii Y, Sakumi K, et al. Targeted disruption of the Rad51 gene leads to lethality in embryonic mice. Proc Natl Acad Sci USA. 1996;93(13):6236-6240.

[160] Kanaar R, Troelstra C, Swagemakers SM, et al. Human and mouse homologs of the Saccharomyces cerevisiae RAD54 DNA repair gene: evidence for functional conservation. Curr Biol. 1996;6(7):828-838.

[161] Chen F, Nastasi A, Shen Z, Brenneman M, Criss- 
man H, Chen DJ. Cell cycle-dependent protein expression of mammalian homologs of yeast DNA doublestrand break repair genes Rad51 and Rad52. Mutat Res. 1997;384(3):205-211.

[162] Vispe S, Cazaux C, Lesca C, Defais M. Overexpression of Rad51 protein stimulates homologous recombination and increases resistance of mammalian cells to ionizing radiation. Nucleic Acids Res. 1998;26(12):2859-2864.

[163] Takata M, Sasaki MS, Sonoda E, et al. Homologous recombination and non-homologous end-joining pathways of DNA double-strand break repair have overlapping roles in the maintenance of chromosomal integrity in vertebrate cells. EMBO J. 1998;17(18):54975508.

[164] Saintigny Y, Delacote F, Vares G, et al. Characterization of homologous recombination induced by replication inhibition in mammalian cells. EMBO J. 2001;20(14):3861-3870.

[165] Kowalczykowski SC. Initiation of genetic recombination and recombination-dependent replication. Trends Biochem Sci. 2000;25(4):156-165.

[166] Haber JE. Partners and pathwaysrepairing a doublestrand break. Trends Genet. 2000;16(6):259-264.

[167] Marians KJ. Replication and recombination intersect. Curr Opin Genet Dev. 2000;10(2):151-156.

[168] Rothstein R, Michel B, Gangloff S. Replication fork pausing and recombination or "gimme a break". Genes Dev. 2000;14(1):1-10.

[169] Schiestl RH, Gietz RD, Mehta RD, Hastings PJ. Carcinogens induce intrachromosomal recombination in yeast. Carcinogenesis. 1989;10(8):1445-1455.

[170] Carls N, Schiestl RH. Evaluation of the yeast DEL assay with 10 compounds selected by the International Program on Chemical Safety for the evaluation of short-term tests for carcinogens. Mutat Res. 1994;320(4):293-303.

* Corresponding author.

E-mail: rschiestl@mednet .ucla.edu

Fax: +1 310267 2578; Tel: +1 3102672087 

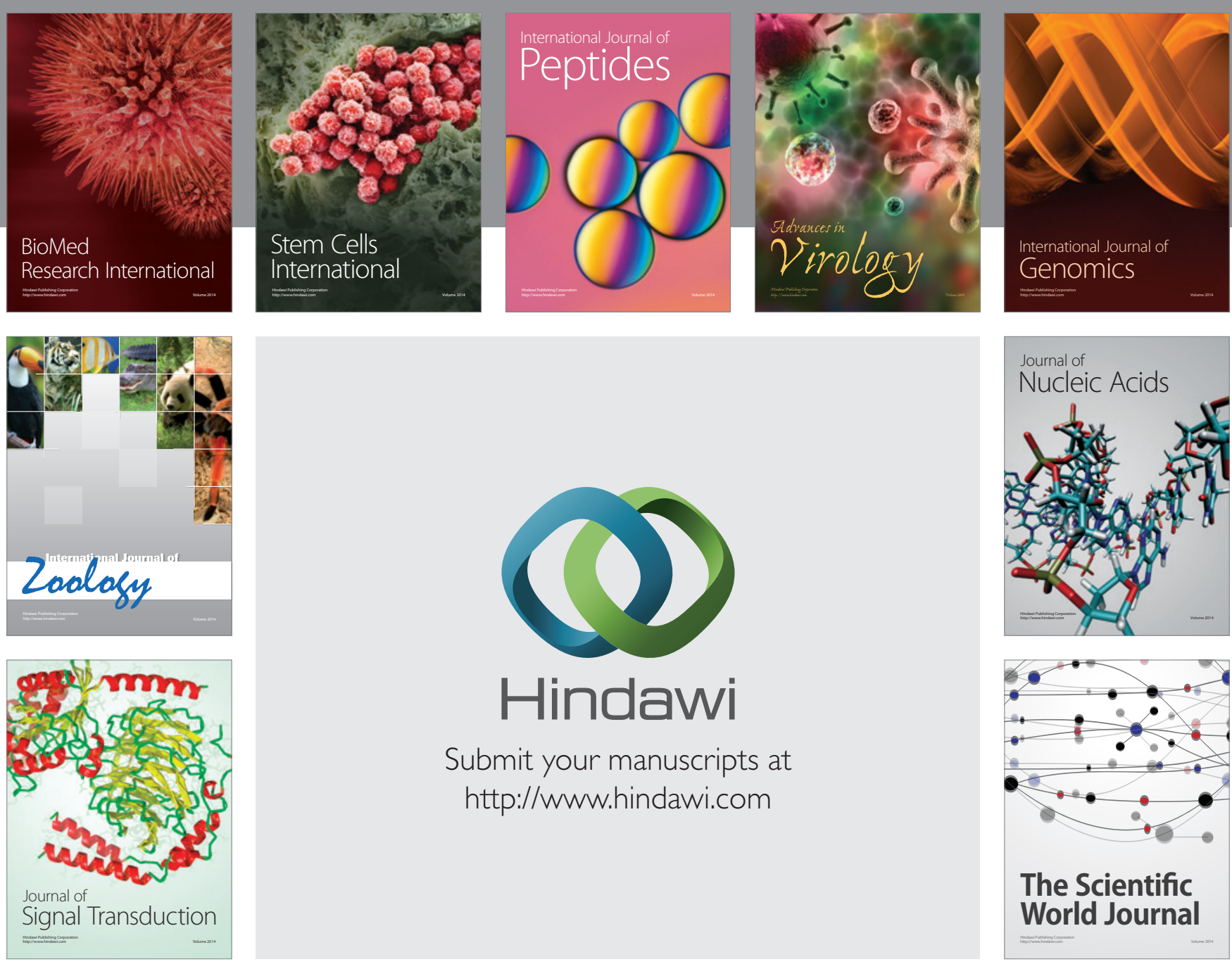

Submit your manuscripts at

http://www.hindawi.com
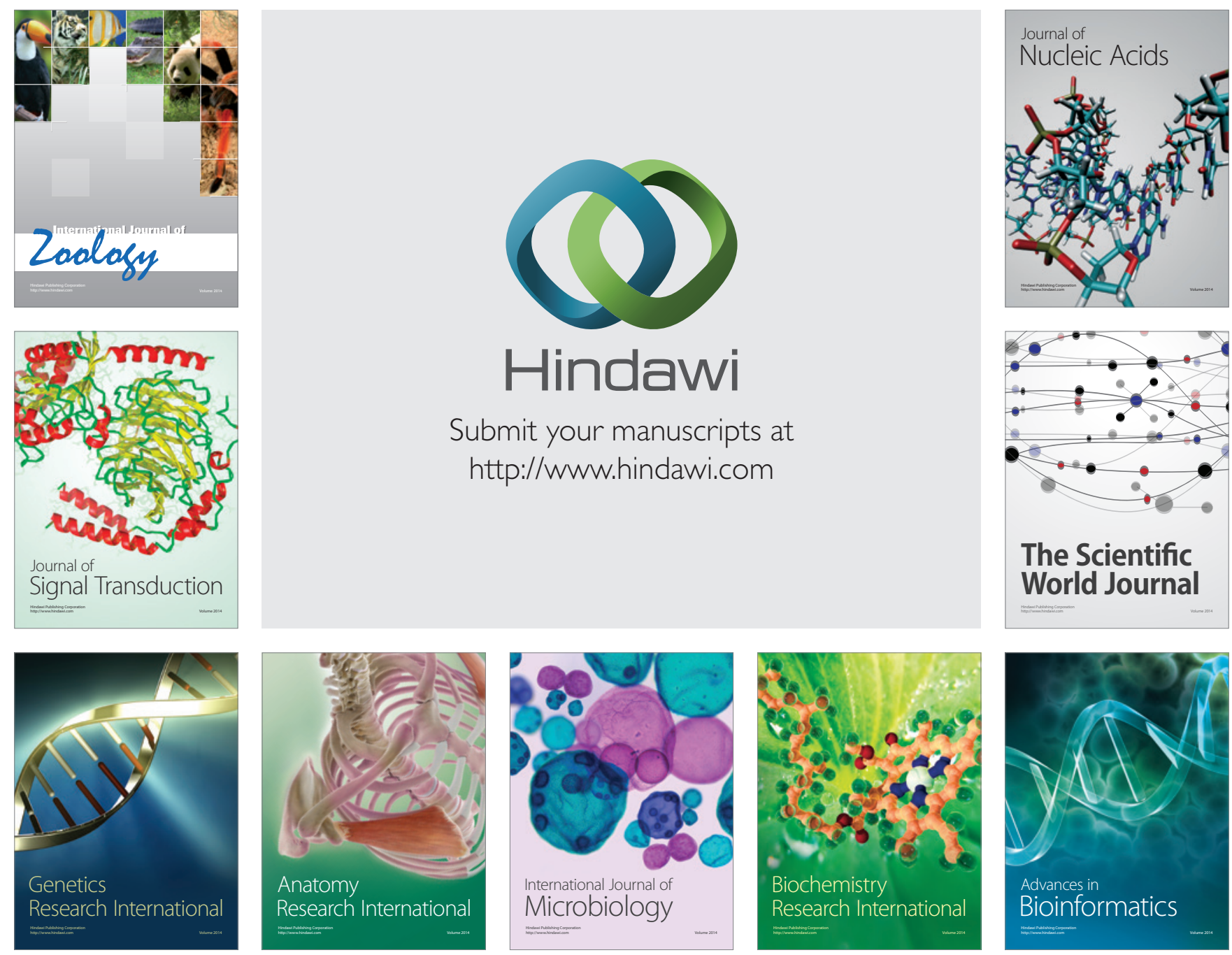

The Scientific World Journal
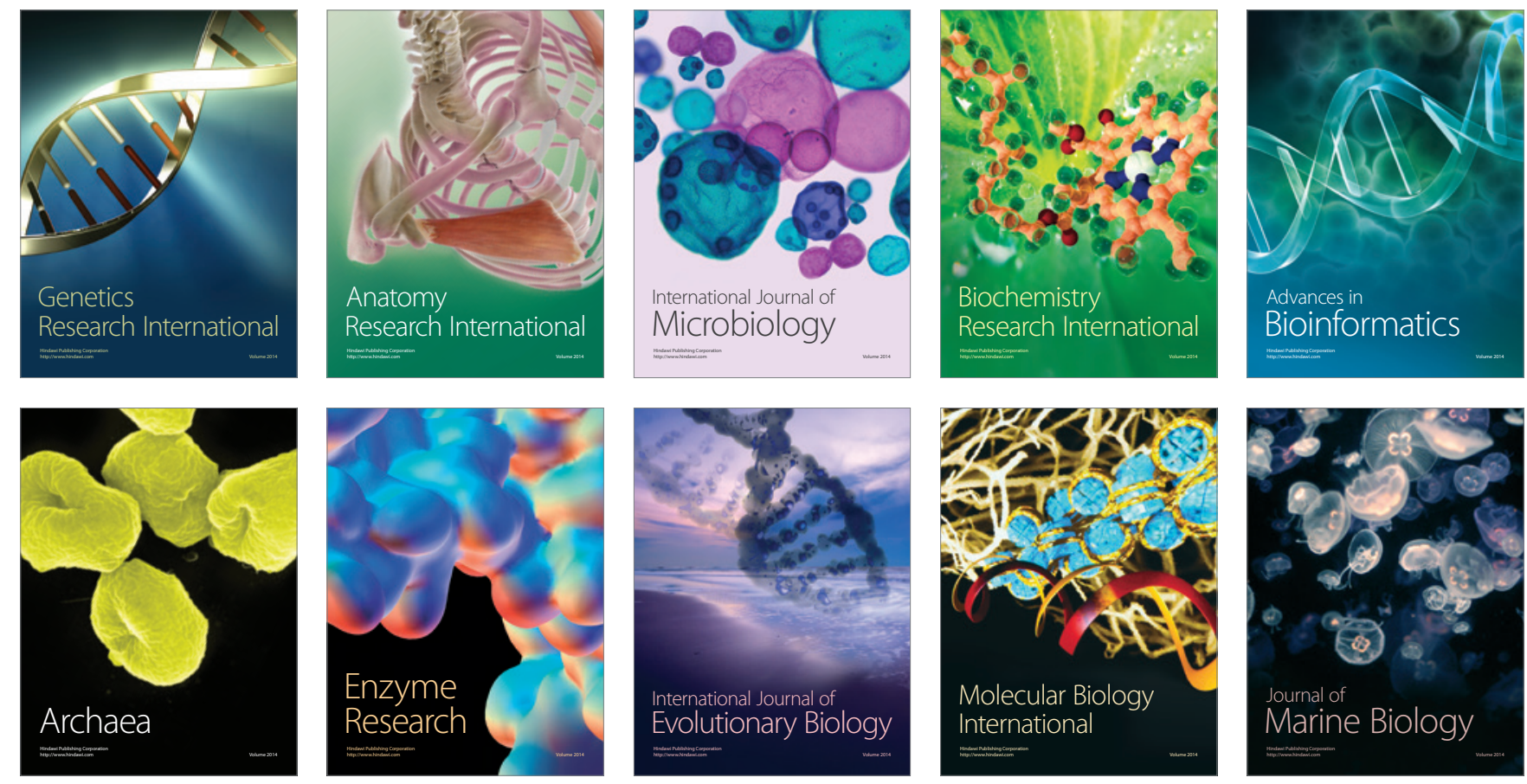